\title{
EDITORIAL
}

\section{"Boleh Belajar dari Luar Negeri, Namun Perlu Berusaha Sebagai Pencipta untuk Mengatasi Masalah Bangsa"}

Pertama-tama kami sangat bahagia dapat menghadirkan Jurnal Kesehatan Komunitas (Journal of Community Health) Volume 1, Nomor 1, November 2010, yaitu majalah ilmiah terbitan pertama yang merupakan inisiatif dari Sekolah Tinggi Ilmu Kesehatan Hang Tuah Pekanbaru. Tujuan dari penerbitan majalah ilmiah ini adalah supaya para pembaca dari kalangan perguuan tinggi, praktisi yang kegiatannya terkait dengan kesehatan dan masyarakat dapat menerima informasi yang bermanfaat bagi kesehatan komunitas di wilayah nya; lebih dari itu mereka dari perguruan tinggi dan praktisi itu dapat pula mengirimkan karya ilmiah mereka ke Jurnal Kesehatan Komunitas ini, sehingga terjadi pertukaran informasi yang akhirnya diharapkan bermanfaat bagi perbaikan kesehatan masyarakat yang lebih menyeluruh.

Dalam penerbitan pertama ini, dalam makalah pertama yang berjudul Perubahan Eksternal, Soft Skills Dan Kurikulum Kesehatan, penulis menyoroti kepentingan tingkah laku kesehatan rumah tangga yang perlu didorong dan direkayasa untuk meminimumkan efek dari penyebaran virus. Dengan demikian penyebaran penyakit-penyakit seperti AIDS, Flu Burung, Flu Babi, Demam Berdarah dan lain-lain yang cukup memusingkan mereka yang bertanggung jawab dalam pelayanan kesehatan, penulis mengusulkan pemutakhiran kurikulum yang tentunya bermanfaat untuk memajukan pendidikan kesehatan kepada rumah tangga, khususnya pendidikan keperawatan, unsur soft skills yang sangat penting, selain perobahan kognitif.

Sejalan dengan pemutakhiran kurikulum tersebut di atas, dalam makalah kedua yang berjudul Pelaksanaan FETP sampai Pemunculan ETMP, penulis membahas pelaksanaan Pendidikan Magister Kesehatan Masyarakat Peminatan FETP (Field Epidemiology Training Program ), yang merupakan program pendidikan yang berasal dari CDC Atlanta Amerika Serikat, dan dilaksanakan di negara-negara lain di luar Amerika Serikat. Namun pelaksanaannya di Indonesia tidak seutuhnya sama dengan pelaksanaannya di negara asal. Pada abad 21 ini, di tanah air sudah berkembang ide, konsep dan rencana untuk mengembangkan pendidikan kesehatan masyarakat yang tidak hanya bersifat akademis tapi juga bersifat profesional, untuk mana telah dibentuk Majelis Kolegium Kesehatan Masyarakat Indonesia yang terdiri atas 8 kolegium antara lain Kolegium Epidemiologi, yang telah menghasilkan Standar Profesi Epidemiologi yang berisi standar kompetensi, standar pendidikan termasuk kurikulum epidemiologi bagi pendidikan yang bersifat akademis ataupun profesional. Di samping itu telah dihasilkan pula kurikulum untuk Pendidikan Magister Kesehatan Masyarakat Peminatan Epidemiologi Terapan untuk Manajemen Pelayanan/Program (ETMP). Namun timbul pertanyaan apakah kurikulum yang dihasilkan oleh anak bangsa ini sudah ada 
di negara lain atau di kalangan internasional. Sehubungan dengan pertanyaan ini, perlu dimunculkan semboyan "Boleh belajar dari luar negeri, namun perlu berusaha sebagai Pencipta untuk mengatasi Masalah Bangsa."

Supaya anak bangsa kita mempunyai daya cipta, dalam makalah ketiga yang berjudul Keberhasilan Pelaksanaan Inisiasi Menyusu Dini (IMD) Di Rumah Bersalin Dan Balai Pengobatan Taman Sari Pekanbaru, penulis dalam penelitiannya menemukan bahwa pelaksanaan IMD belum terlaksana dengan baik dan benar dan pelaksanaan IMD belum berhasil. Pengetahuan ibu tentang IMD masih rendah sehingga ibu tidak termotivasi untuk melaksanakan IMD sampai berhasil. Inisiasi Menyusu Dini merupakan salah satu upaya untuk meningkatkan cakupan ASI eksklusif.
Bila ibu dapat melaksanakan ASI Ekslusif kepada bayi nya, maka dapat diharapkan pertumbuhan dan perkembangan bayi dapat berjalan secara optimal baik fisik dalam arti kognitif ataupun mental sehingga mereka mempunyai tingkat emosi dan spritual yang tinggi, yang menjadi dasar bagi pertumbuhan manusia menuju sumber daya manusia yang baik dan lebih mudah untuk menyayangi orang lain. Dengan demikian diharapkan pada masa dewasa mereka di samping mempunyai kemampuan kognitif yang baik, juga mempunyai soft skill yang diharapkan. Selanjutnya pendidikan harus diarahkan supaya lulusan mempunyai kemampuan kognitif, psikomotorik dan afektif yang terpadu sehingga dapat diciptakan anak bangsa pencipta yang mengabadi untuk mengatasi masalah bangsanya. 